Spinoza's Authority Volume I: Resistance and Power in Ethics 


\begin{abstract}
Also available from Bloomsbury
Conflict, Power, and Multitude in Machiavelli and Spinoza, Filippo Del Lucchese

Spinoza and the Specters of Modernity, Michael Mack
\end{abstract}

Between Hegel and Spinoza, edited by Hasana Sharp and Jason E. Smith

Spinoza: Ethics of an Outlaw, Ivan Segré

Spinoza's Authority Volume II, edited by A. Kiarina Kordela and Dimitris Vardoulakis

The Role of God in Spinoza's Metaphysics, Sherry Deveaux

Bloomsbury Companion to Spinoza, edited by Wiep van

Bunge, Henri Krop, Piet Steenbakkers and Jeroen van de Ven 


\title{
Spinoza's Authority Volume I: Resistance and Power in Ethics
}

\author{
Edited by \\ A. Kiarina Kordela and Dimitris Vardoulakis
}

Bloomsbury Academic

An imprint of Bloomsbury Publishing Plc

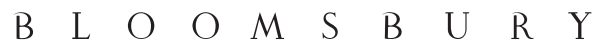
LONDON • OXFORD • NEW YORK • NEW DELHI • SYDNEY 


\title{
Bloomsbury Academic
}

An imprint of Bloomsbury Publishing Plc
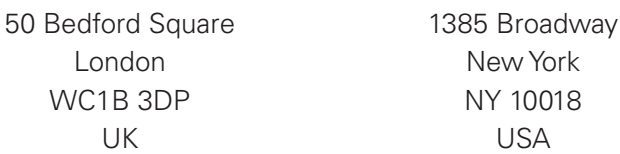

www.bloomsbury.com

\section{BLOOMSBURY and the Diana logo are trademarks of Bloomsbury Publishing PIc}

\author{
First published 2018
}

(c) A. Kiarina Kordela, Dimitris Vardoulakis and contributors, 2018

A. Kiarina Kordela and Dimitris Vardoulakis have asserted their right under the Copyright,

Designs and Patents Act, 1988, to be identified as Author of this work.

All rights reserved. No part of this publication may be reproduced or transmitted in any form or by any means, electronic or mechanical, including photocopying, recording, or any information storage or retrieval system, without prior permission in writing from the publishers.

No responsibility for loss caused to any individual or organization acting on or refraining from action as a result of the material in this publication can be accepted by Bloomsbury or the author.

\section{British Library Cataloguing-in-Publication Data}

A catalogue record for this book is available from the British Library.

$$
\begin{array}{rrr}
\text { ISBN: } & \text { HB: } & 978-1-4725-9320-7 \\
& \text { ePDF: } & 978-1-4725-9322-1 \\
& \text { ePub: } & 978-1-4725-9321-4
\end{array}
$$

\section{Library of Congress Cataloging-in-Publication Data}

A catalog record for this book is available from the Library of Congress.

Series: Bloomsbury Studies in Continental Philosophy

Typeset by Integra Software Services Pvt. Ltd. 


\section{Contents}

Preface A. Kiarina Kordela and Dimitris Vardoulakis vi

Acknowledgments vii

Reference Guide viii

Authority in the Ethics: An Introduction A. Kiarina Kordela 1

1 Equality and Power: Spinoza's Reformulation of the Aristotelian Tradition of Egalitarianism Dimitris Vardoulakis $\quad 11$

2 Spinoza's Ethics and Politics of Freedom: Active and Passive Power Aurelia Armstrong 33

3 Grammars of Conatus: Or, On the Primacy of Resistance in Spinoza, Foucault and Deleuze Cesare Casarino $\quad 57$

4 Beyond Legitimacy: The State as an Imaginary Entity in Spinoza's Political Ontology Juan Domingo Sánchez Estop 87

5 The Cold Quietness of the Stars: Proof, Rhetoric and the Authority of Reason in the Ethics Joe Hughes 113

6 Spinoza: A Different Power to Act Antonio Negri 135

7 Commanding the Body: The Language of Subjection in Ethics III, P2S Warren Montag 147

8 Interrupting the System: Spinoza and Maroon Thought James Edward Ford III 173

9 Spinoza's Biopolitics: Commodification of Substance and Secular Immortality A. Kiarina Kordela 197

$\begin{array}{ll}\text { Biographical Notes } & 218\end{array}$

$\begin{array}{ll}\text { Index } & 220\end{array}$ 


\section{Acknowledgments}

We are thankful to all of our contributors as much for the final products that appear in the form of these thoughtful essays as for what came before that: their enthusiastic engagement in conference panels and workshops that have helped us all shape our ideas as we were putting them down in essay forms. These events include: the seminar on "Spinoza's Authority," organized by Dimitris Vardoulakis, which took place at the University of Western Sydney, in Sydney, Australia, in August 2012; the thematic stream on "Spinozan Politics" at the London Conference on Critical Thought, organized by Filippo Del Lucchese and Dimitris Vardoulakis, which took place at the Royal Holloway, University of London, in June 2013; the seminar on "Spinoza's Authority: Resistance and Power" at the conference of the American Comparative Literature Association, organized by Siarhei Biareishyk and A. Kiarina Kordela, which took place at the New York University in New York, in March 2014; and the workshop on "Spinoza's Theologico-Political Treatise," organized by Stathis Gourgouris and Dimitris Vardoulakis, which took place at Columbia University in New York, in November 2015. 


\section{Reference Guide}

\section{References to Spinoza's works}

The various translations of Spinoza's works offer often significantly different interpretation of the meaning of his original Latin text. For this reason, the contributors have been free to choose their preferred translation, or to translate themselves the Latin from the established text of Spinoza's works in the Gebhardt edition of the Opera.

The following abbreviations of specific works have been used:

$E=$ Ethics [Ethica]

The Roman numeral in capital following $E$ indicates the part of the Ethics. For example, E I is Ethics, Part I, E II is Ethics Part II, and so on. The following abbreviations have been used here:

$$
\begin{aligned}
& \text { A = Axiom } \\
& \text { Ap. }=\text { Appendix } \\
& \text { C = Corollary } \\
& \text { D = Definition } \\
& \text { L = Lemma } \\
& \text { P = Proposition } \\
& \text { Pr = Proof } \\
& \text { Pref = Preface } \\
& S=\text { Scholium }
\end{aligned}
$$

So, for instance, E II, P7 refer to Ethics, Part I, Proposition 7. And, E IV, P34S refers to Ethics, Parts IV, Scholium to Proposition 34.

\section{Other abbreviations to Spinoza's works}

TIE (Treatise on the Emendation of the Intellect): cited by paragraph number.

Ep. (The Letters): cited by letter number.

PC (Principles of Cartesian Philosophy).

ST (Short Treatise). 
TP (Tractatus Politicus): cited by chapter followed by paragraph number. TTP (Tractatus Theologico-Politicus).

The contributors indicate in each chapter which edition of the above works they prefer to use. 


\title{
Equality and Power: Spinoza's Reformulation of the Aristotelian Tradition of Egalitarianism
}

\author{
Dimitris Vardoulakis
}

\section{Equality in the Axiom to Part IV of the Ethics}

There is an almost unanimous agreement on Spinoza's democratic credentials, which is surprising, given, the wildly divergent interpretations on Spinoza's philosophy. ${ }^{1}$ And yet, it is next to impossible to find any discussion of equality in Spinoza's work. ${ }^{2}$ Partly this is due to Spinoza himself, who refers to equality sporadically but never systematically. ${ }^{3}$ For instance, Spinoza mentions in Chapters 16 and 17 of the Theological-Political Treatise that both in democracy as the "most natural constitution" and in the "theocracy" of Hebrew state people enjoyed equality, but this does not seem to suggest much more than that in both of these cases the citizens do not transfer their natural right to another human person. This absence of a sustained discussion of equality in Spinoza raises a problematic: Is it possible to defend a theory of democracys without a sense of equality? Or is it perhaps the case that Spinoza never thematizes equality explicitly because it is included within another concept? I will argue that the latter is the case. Spinoza's sense of equality is inextricably linked to his conception of power and the production of state authority.

One could point out, of course, that equality has always been an aspect of state authority, at least since the Solonian reforms that lead to the writing of the first ever democratic constitution. As Aristotle explains in The Athenian Constitution, the cause of these reforms was the violent dispute between the rich and the poor parties due to stark inequalities within Athens. ${ }^{4}$ Around 594 BC, the Athenians turned to Solon - widely regarded as both wise and impartial - to find a solution to these constant struggles. Solon instituted three fundamental reforms to promote equality. First, he canceled the debts and redistributed the wealth (this is the famous reform of seisachtheia, the shaking of the burdens). Second, he extended 
citizenship to all, whereas in the past citizenship was confined only to the rich. And lastly, everyone was expected to participate in public office through a process that relied on chance-election by lot. ${ }^{5}$ In these three reforms, we can discern the three senses of equality that have dominated Western political discourse ever since. Namely, there is the material equality of wealth redistribution; the procedural equality before the law by granting everyone citizenship; and, the equality of worth whereby one is deemed to deserve to hold office.

I will return to these three senses of equality in the next section. I need to point out here three points: First, it is Aristotle who thematizes the three senses of equality under the rubric of geometric equality in Nicomachean Ethics, which has had an enormous influence in how equality has been thought ever since in the Western political and philosophical tradition. Second, the three senses confine equality within state authority, or, to put it different, equality is raised to a significant political virtue. It is for this reason that I call the various permutations and combination of the three senses of geometric equality state equality. Third, Jacques Rancière has made a pivotal contribution is highlighting the origins of the modern thinking of equality and its links to state power. ${ }^{6}$ (For reasons of space I cannot deal with Rancière in this chapter. $\left.{ }^{7}\right)$ My argument concentrates on Spinoza to show that he is skeptical of the authority produced by state equality, which explains why he both avoids an explicit thematization of equality, and why equality is in fact subordinated to his conception of power.

Further, my contention is that the central axis of the thinking of equality in Spinoza is provided by the Axiom to Part IV of the Ethics. Many have noted the importance of this axiom. For instance, Antonio Negri in Savage Anomaly insists that "this axiom constitutes the dynamic center of Spinoza's philosophy." Negri's assessment is related to the fact that the Axiom to Part IV posits an imbrication of the ontological and the political. My further assertion is that this imbrication resonates with a thinking of equality-moreover, a thinking that will appear to be incompatible with the Aristotelian extrapolation of geometric equality, which has dominated the Western philosophical tradition.

Let us examine the axiom, which at first glance may appear deceptively simple. The Axiom to Part IV of the Ethics reads:

There is no singular thing in Nature than which there is not another more powerful [potentior] and stronger [fortior]. Whatever one is given, there is another more powerful by which the first can be destroyed. (E, IV, A1)

The first noticeable aspect of this axiom is that it coposits being and power. The axiom expresses the imbrication of the ontological and the political. This 
imbrication, significantly, introduces inequality of power. Ultimately, everyone will be overpowered by an external cause. For an attentive reader of the Ethics, this should come as no surprise. Already Proposition 28 of Part I of the Ethics announces that every finite mode has a cause, which entails that there is always something more powerful than us because we are all subject to external causes and something acts upon us as a cause if it is stronger than us. ${ }^{9}$ The difference from the earlier Proposition 28 is that in Part I the idea is discussed from the perspective of the modes, whereas the Axiom to Part IV articulates the idea in terms of how power unfolds within the totality of the single substance, or Nature. This consolidates the interdependence of power and the ontological. Power is not simply a political concept-it is not solely potestas. Power also has an ontological dimension-it is potentia. Being, for Spinoza, is political.

To delineate Spinoza's critique of equality, we need to elaborate on the three senses of equality mentioned above. These are the senses of procedural, material and desertful equality. These three senses work in tandem to produce political authority. But the image of the authority presented is different, depending on whether the three senses are presented as working in tandem, or as being in conflict, or, finally, whether a sense of harmony or equilibrium based on equality is posited as an ante-political space. By positioning himself against these three different ways that the three senses of equality have been organized in the Western philosophical thought in order to produce state equality, Spinoza suggests his own conception of equality.

\section{The three senses of equality in collaboration: The production of authority}

To discern both the critical aspect of Spinoza's reworking of equality and the positive articulation of his position, it is necessary to start with Aristotle, who developed in the Nicomachean Ethics the earliest sustained discussion of equality that has survived in the philosophical canon and which has had a profound influence in subsequent elaborations of state equality in theory and in politics. According to Book V of the Nicomachean Ethics, equality is a species of justice. ${ }^{10}$ Aristotle distinguishes two types of equality. One is referred

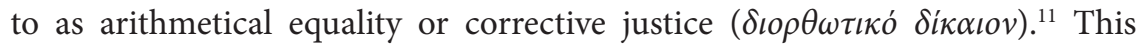

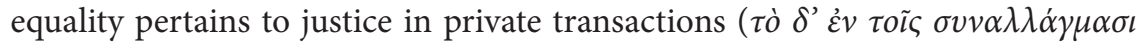
$\delta i \kappa \alpha \iota v v) .{ }^{12}$ Aristotle's example is of a judge who needs to determine reparations for damages. The judge's job is to determine the equality between the loss and 
its compensation. For instance, if someone steals $\$ 10$ he should repay exactly the same amount. From a political perspective, geometrical equality is the significant one. ${ }^{13}$ This is a distributive justice ( $\tau \dot{\alpha} \dot{\varepsilon} v \delta \iota \alpha v o \mu \tilde{n} \delta i \kappa \alpha \iota v v$ ) that utilizes a value or merit to determine equality by analogy. ${ }^{14}$ "All are agreed that justice in distributions must be based on desert of some sort." ${ }^{15}$ Equality in a political context is not determined by a mathematical formula but by what one deserves.

The sense of geometric equality has dominated the Western philosophical tradition-or, to be more precise, a problem about geometric equality that Aristotle is acutely aware of has been the major source of thinking about state equality in political theory. Aristotle immediately qualifies his assertion about the universal agreement on desertful equality: "although they do not all mean the same sort of desert." Geometric equality gives rise to a fundamental political dispute-to which we will turn later. Aristotle continues: "democrats make the criterion free birth; those of oligarchical sympathies wealth; ... upholders of aristocracy make it virtue." ${ }^{16}$ These three different senses of geometric equality provide, then, three different determinations of the desert or merit of political equality. I pointed out in the previous section that all three were present in Solon's reforms, which established state equality, and I identified them, respectively, as the procedural equality, as material equality and as equality of worth. Aristotle is clear that equality is not some kind of metaphysical quality but a way in which the three regimes of constituted power that his system allows-a classification which remains totally unchallenged at least until the development of the social contract tradition two millennia later-anticipate the legal context of power relations between citizens. We can draw an analogy from Aristotle's position of equality as a species of justice to say that within this tradition the different forms of constituted power-democracy, oligarchy, and aristocracy-are species of equality. Equality is the sense of justice that underwrites political regimes of power.

Almost every theory of state equality includes all three forms of equality, but privileges only one of them. ${ }^{17}$ The way that the three senses of equality work together determines which regime is preferred. We can give an example by turning to John Rawls' theory of justice as fairness. Rawls indicates that his aim is to use the notion of pure procedural justice as the basis of his theory. This leads him to reformulate the traditional notion of the state of nature to what he calls "an original position." This is envisaged as stripped of all personal interests-in Kantian terms, it is separate from natural causality-and thereby leaves individuals equal to exercise their rationality to form moral principles of justice. ${ }^{18}$ At the same time, Rawls distinguishes two principles of justice. The 
first principle is the articulation of the original equality into a system of rights. This corresponds to what I called "procedural equality." The second principle is concerned with how to deal with social and economic inequalities. Under this second principle, Rawls tackles the issue of material equality and equality of worth (e.g., under the topic of the equality of opportunity). However, consistent with the starting point that expresses a pure procedural justice, Rawls insists on a hierarchy of principles, whereby the first principle strictly precedes the second one. Thus Rawls both deals with all three forms of equality and at the same times privileges one of them, the procedural. This becomes the basis for legitimating political authority - it forms the basis of the kind of liberal democracy that Rawls advocates.

The strategy of utilizing all three forms of geometric justice in legitimizing authority is typical of the way in which Western philosophical thought has approached state equality. It is important to note that the same three ingredients can be-and have been-used to develop anti-democratic positions about equality. The binding element is that the three senses of equality are all retained even though a justification is provided as to why one of them is privileged. For instance, the Greek neo-Nazi party, Golden Dawn, describes its "Identity" in twelve propositions. The last one reads: "The Popular state of Nationalism determines that equal opportunity is based on worth and it does not ignore the law of difference in Nature. Respecting the mental, national and genetic inequality of humans we can build a just society of equality before the law." ${ }^{\prime 19}$ The three senses of equality are easily identifiable. Both the procedural equality before the law and the material equality of equal opportunity are based on an equality of worth, which is understood in racial terms by appeal to some kind of natural law of difference. I do not want to engage here with the content of this argument but to point out its form, which privileges one while identifying all three forms of geometric equality that Aristotle defines in Nicomachean Ethics. In the sense that Golden Dawn uses the three senses of equality in order to legitimate its actions and authority, this neo-Nazi determination of equality aligns itself with the Western philosophical tradition of thinking about state equality in terms of the Aristotelian geometric equality.

The Axiom to Part IV of the Ethics speaks of inequality of power in the sense that it is incommensurate with state equality. The "in" of "inequality" is a privative not of equality tout court but of the three senses of equality that we have inherited from Aristotle's geometric equality. But what is it exactly that the Axiom to Part IV rejects? The short answer is: authority. Spinoza seeks to define a sense of equality in democracy that is distinct from the sense of state equality 
related by the tradition. Spinoza uses the ontological dimension of the Axiom to Part IV - the fact that everyone can be overpowered by external causes- to show the importance of building communities where power is shared. According to Proposition 36, "The greatest good of those who seek virtue is common to all, and can be enjoyed by all equally." Spinoza argues for a common space where democracy unfolds because of the power interactions of the citizens. It is important to recall here that according to Definition 8 of Part IV of the Ethics, "virtue and power ... [are] the same thing." The seeking of virtue unfolds within differential power dynamics where power is never distributed equally between the participants. Even though-or, rather, because-the power dynamics are never in a state of equilibrium, Spinoza still insists on a sense of equality. Spinoza's is an equality in the participation and engagement of contestation. Or, in Spinoza's terms, virtue as power is not a quality that is given in advance and independently of the particular situation only in order to legitimate authority, but rather the enactment of one's power in a space in common with others. The Axiom to Part IV is the Spinozan expression of equality.

The question, then, becomes: How can Spinoza's equality respond to the political authority produced by the collaboration between the three senses of equality? Or, differently put, how can the imbrication of the ontological and the political deal with consolidated forms of constituted power? Filippo del Lucchese gives a simple and compelling answer in Conflict, Power, and Multitude in Machiavelli and Spinoza. At the heart of his account is the Axiom to Part IV understood in ontologico-political terms. The reason is that the axiom establishes a relational ontology, which consists in the mutual limitation of entities. As Lucchese puts it: "Relationship immediately takes precedence over essence and the relationship involved is primarily conflictual."20 The conflictual nature of this relational ontology leads Lucchese to argue that Spinoza develops a theory of agonistic democracy. As I have argued elsewhere, a relational ontology offers the means both to resist constituted power and to create a space to encounter the other as a partner and agonist. ${ }^{21}$ Differently put, echoing Lucchese's vocabulary, there is no essence in the justification of violence characteristic of sovereignty, while at the same time being is conflictual.

As a consequence, the Axiom to Part IV prevents the assumption of an absolute political power. To make this point, Lucchese turns to Proposition 28 of Part I of the Ethics, which, as already intimated, is closely linked to the Axiom to Part IV. Proposition 28 holds that every finite mode has a determinate causethe position which the Axiom to Part IV generalizes to include the whole of nature. In the important Scholium to Proposition 28, Spinoza notes that "God is 
absolutely the proximate cause of the things produced immediately by him." The insertion of God within the realm of causality that ultimately includes everything that exists opposes a conception of the divine as standing outside the laws of nature and directing at will human affairs. In other words, "the idea of reciprocal determination of finite things" not only rejects "the Aristotelian doctrine of the prime mover and the idea of transitivity in the relationship between cause and effect." In addition, Lucchese continues, it "impedes us from modeling reality in terms of a finalistic explanation." 22 Now, this has clear political implications. Just as Spinoza's God is part of all the relations between beings and cannot be said to stand outside or above these relations, similarly the sovereign is part of the relations between citizens but without standing above the law dictating, as if from above, political actions. A sovereign's authority is delimited by the conflictual nature of relationality. To understand authority from the perspective of the Axiom to Part IV and of equality entails that a sovereign is always subject to be overpowered by the people. A "sovereign power [is] continuously exposed to the judgment ... of its subjects." ${ }^{23}$ Or, to provide another quotation that encapsulates the main thesis of Lucchese's important book: "Whenever there is a power [i.e. constituted power], there is also resistance." ${ }^{24}$ Such a conception, then, of agonistic democracy, as it arises out of the Axiom to Part IV, necessitates the limitation of political authority. No authority can hold itself to be absolute because it is always liable to be overpowered.

\section{The three senses of equality in conflict: The destruction of the polis}

There is also a long tradition within political philosophy, also going back to Aristotle, which does not focus on the production of power through the synergies between the three senses of equality, but rather on how the antagonism between the three senses of equality results in destructive political conflict. It is no longer about how the political authority is produced; rather, it is about which political authority prevails-it is not the genetic question but rather the question of realist politics. This different move is most evident in Aristotle's Politics.

In Book V of Politics, Aristotle singles out equality as the cause of the most abominable kind of conflict, civil war. ${ }^{25}$ In the opening of Book V, echoing the Nicomachean Ethics, Aristotle specifies the three constitutions in terms of how each of them defines geometric equality, while also arguing that the dispute about the different determinations of equality is destructive: "Democracy 
arose from men's thinking that if they are equal in any respect they are equal absolutely, ... oligarchy arose from their assumption that if they are unequal as regards some one thing they are unequal wholly."26 The dispute between the democrats and the oligarchs is about state equality. This dispute about equality between democrats and oligarchs is the "principal cause" of conflict in the city. ${ }^{27} \mathrm{At}$ the same time, aristocracy is not immune from the influence of equality in precipitating infighting: "And of all men those who excel in virtue would most justifiably stir up faction [ $\sigma \tau \alpha \sigma i \alpha \dot{\zeta} \zeta o ı v]$, though they are the least given to doing so." ${ }^{28}$ The most desertful ones are the most justified in leading a dispute, even though their superior virtue, contends Aristotle, prevents them from doing so.

The tripartite sense of political equality extrapolated by Aristotle asserts political authority. But such a constituted power is not an authority that is universally acceptable. Nor is it an authority immune from attack. It is a contested authority that is liable to change. What happens, however, when such change is resisted by constituted authority or when conflicting interests clash? At this point there arises the possibility of bloody conflict that is destructive of the polis. The notion of state equality has always been accompanied by the threat of such a destruction. And even if equality is not always perceived as the primary cause of civil war, still it is rare to see a call to revolt without support from the concept of equality, in whatever sense it may be configured.

The agonistic description of the political arising from Proposition 36 to Part IV of the Ethics_- "The greatest good of those who seek virtue is common to all, and can be enjoyed by all equally"-is radically distinct from bloody conflict. Instead, Spinoza sees in it the possibility of collaboration or a space of commonality. Proposition 37 of Part IV asserts: "The good which everyone who seeks virtue wants for himself, he also desires for other men." I will return to this proposition in more detail later, but suffice to say here that for Spinoza the other is not an entity with a distinct identity. One's identity is produced through the other. What one thinks and what one desires are not autonomous activities but rather conditioned in a process of transformation that is precipitated by the other. One's being is always a being with. Here, ontology and power meet, since for Spinoza virtue is power. And this also means that the ontological and the political converge on this site. The political import of this insight is highlighted by Spinoza himself, who asserts in Scholium 1 to Proposition 37 that "I have ... shown what the foundations of the state are."

There is one important implication of this reconfiguration of conflict so that it is no longer a struggle for power but rather the struggle of power: Because no one is immune from being overpowered by external causes, because everyone 
is subjected to external causes, Lucchese observes, "the collective body holds more absolute power." ${ }^{29}$ Here is perhaps a definition of the multitude from the perspective of the Axiom to Part IV: the struggle that takes place in interpersonal relations, and which resists at any point subordination to a single authority. From this perspective, the constitutive characteristic of democracy is not procedural, material or desertful equality, but rather the agon that is possible because of differential power and which creates the multitude. From this perspective, the multitude is the community that is held together by the conflictual relations necessitated by the inequality of differential power.

\section{Equality as ante-political: Equality and the construction of sovereignty}

Can a founding account of political authority, which also bypasses the conflict between the different senses of geometric equality, be given? The question of the foundation of political authority is intertwined with the justification of the operation of power. The foundation of political authority that also seeks to resolve the conflict of equality has been a significant and oft-repeated move. It consists in the positing of an ante-political space of equality, which leads to various formulations of state equality. This is a crucial and complex move in political theory, since it develops alongside the conception of sovereign power.

I only have time to discuss here very few facets of this complex move, and I will necessarily have to rely on the genealogy of sovereignty that I develop in my Sovereignty and Its Other. I distinguish there between three types of sovereignty-ancient, modern and biopolitical. I argue that each form of sovereignty has its own logic, even though they are all related. I will present here how these three forms of sovereignty are depend on the presupposition of an ante-political space of equality, and how Spinoza's conception of equality counters all three conceptions. I will present the three positions with references to specific philosophers, namely, Augustine, Hobbes and Kant.

\section{Augustine: Ancient sovereignty}

Augustine's relating of the Fall is the source of the conception of an antepolitical equality in the same move that constructs the free will. What in Genesis was the Garden of Eden, becomes in Augustine paradise (paradiso) as a space of perfect happiness: "How happy, then, were the first human beings, 
neither troubled by any disturbance of the mind not pained by any disorder of the body!" ${ }^{30}$ As a result of this harmony and equilibrium, "in Paradise ... there arose in him who dwelt there no desire or fear to hinder his good will. ... A faithful fellowship of honest love existed." ${ }^{31}$ The story of the paradise is not simply an allegory, according to Augustine, but a true reality in which such an equality existed. ${ }^{32}$ It was only when the protoplasts, through "an act of free will," ate the forbidden fruit that they became subject to $\sin .^{33}$ There is free will in order for morality to exist, which in its turn underwrites political authority. But the exercise of the free will takes place in a space of absolute happiness and equality. The Augustinian transformation of the Garden of Eden into such a paradise becomes the prototype of the idea of a natural, ante-political space of absolute equality.

It is important to stress the originality of Augustine's account, which resides precisely in the determination of the Garden of Eden as a paradise of perfect happiness and equality and the Fall as the consequence of the original sin of Adam and Eve. This account, the so-called Augustinian theodicy, is not the only account of the expulsion from the Garden of Eden. Besides the wellknown fact that the Genesis does not describe Eden other than as an earthly garden of pastoral simplicity, John Hick also shows in his classic study Evil and the God of Love that there are competing accounts of the Fall in the Eastern Tradition. Hick singles out in particular Irenaeus, who "pictures Adam and Eve in the Garden of Eden as children; and their sin is accordingly not presented as a damnable revolt, but rather as calling forth God's compassion on account of their weakness and vulnerability." ${ }^{34}$ According to this alternative tradition, Eden is no paradise where the protoplasts live in blessed equality, nor is there any need for the invention of the free will in order to account for the Fall. Instead, Adam and Eve are weak, vulnerable and easily deceived. Before Augustine, the idea of a natural, ante-political space of equality is absent. ${ }^{35}$ This idea now provides the Aristotelian conception of geometric equality with a foundation used by the Western political philosophical tradition to account for the genesis of the political. The ante-political equality is not simply the foundation of state equality but foundational of the entire conception of sovereignty.

Spinoza counters Augustinian theodicy as it is clear from the rejection of the distinction between good and evil in the Ethics. According to the preface of Part IV, "good and evil ... indicate nothing positive in things, considered in themselves, nor are they anything other than modes of thinking, or notions we form because we compare things to one another." It is our interpretation of things that makes them good or evil, and this interpretation, as the Axiom to Part IV 
explains, is part of the relations of power that we form with things and other humans. Spinoza continues: "For one and the same thing can, at the same time, be good, and bad, and also indifferent." Eating the apple is definitely something bad for a resident of the Garden of Eden who does not want to be expelled. And yet, eating an apple in the "fallen world" can be nutritious and appealing to the sense of taste. The rejection of the existence of good and evil in the Preface of Part IV of the Ethics is intricately linked both to the Axiom to Part IV and to the definition of virtue as power.

The idea of the natural condition of the human is diametrically different in Spinoza and Augustine. ${ }^{36}$ The Christian Father posits the ante-political naturalness of paradise in order to explain the existence of evil in the fallen world. Spinoza's rejection of good and evil subverts the entire structure of the Augustinian argument that invented a sense of equality as a foundational element of the political. For if there is no good and evil, then that space that generates their existence via the operation of the free will-that is, the ante-political space of equality-also does not exist. What is natural is not a paradisiac garden of absolute equality, but rather the fact that nothing escapes causality and hence everything is subject to be overpowered by something else. Differently put, according to Augustine there is no efficient cause for the existence of evil; rather, its existence out of nothing is the creation of the free will. Spinoza responds that nothing can occur without a cause. There is no creation out of nothing for Spinoza. And this means that there is a natural inequality of power since the cause is always more powerful than the effect.

Significantly, Spinoza's rejection of the possibility of a paradisiac ante-political space entails Definition 8 of Part IV. As we saw earlier, this definition holds that virtue and power are one and the same thing. This means that the political is not confined to human relations regulated either by formally instituted laws or transcendental moral laws, which determine in either case what virtue is. Rather, so long as there is an other, there is power. Being is being with. And virtue consists in the participation within this power dynamic. The co-implication of virtue with power and the rejection of good and evil tightly support each other. They show that for Spinoza the ethical is imbricated with the ontological and the political. Conversely, the morality that arises from the supposition of a paradisiac equality and which underwrites Christian conceptions of sovereignty is precisely the rejection of such an imbrication. The combination of the Axiom to Part IV, which shows the differential power that regulates relations, and Definition 8, which links virtue and power, leads to Spinoza's reconception of equality, which consists in participation in the differential power relations 
within a communal space. The relations cannot be in equilibrium because power is never distributed in equal measure-power is never reducible to geometric equality. Rather, relations unfold in conflict, that is, as the agonistic interactions within a field of relations.

\section{Hobbes: Modern sovereignty}

The modern conception of sovereignty transforms the Augustinian paradise into the concept of the state of nature. This is a significant transformation, which has multiple effects. For instance, the state of nature is now not harmonious but rather a state of war and deadly violence. I do not intend to go into the details of this transformation here. I only want to point that one thing remains constant in the transformation of paradise into the state of nature, namely the positing of an ante-political space of absolute equality. The best example here is Thomas Hobbes' description of the state of nature in Chapter 13 of the Leviathan: "Nature hath made men so equall, in the faculties of body, and mind ... as that one man can thereupon claim to himselfe any benefit, to which another may not pretend, as well as he." There is an absolute equality, not only of mind but even of body, Hobbes says. "From this equality of ability, ariseth equality of hope in the attaining of our Ends." The coupling of equality with the freedom of desire entails that people might have similar ends-people might want the same thing. What is the result of this coupling? "And therefore if any two men desire the same thing, which neverthelesse they cannot both enjoy, they become enemies; and in the way to their End ... endeavour to destroy, or subdue one another." ${ }^{37}$ The result is enmity. Ante-political equality plus freedom-that is, precisely the conjunction that characterizes Augustinian theodicy-is the cause of the war of all against all according to Hobbes. Or, to put the same point in the famous phrase from De Cive, "Man to Man is an arrant Wolfe [Homo homini Lupus]." ${ }^{38}$ For the contractarian tradition, natural man is not a political animal but a carnivore who lusts after its fellow citizen's blood. Only the renunciation of this natural state of equality in favor of the founding of a sovereign state can guarantee order, peace and stability.

Hobbes' extrapolation of the state of nature can be understood as a combination of the Augustinian paradise with the sense of stasis found in Thucydides' History of the Peloponnesian War. A translation of Thucydides' History was the first published work by Hobbes as well as the first ever translation into English of the "father of historiography." ${ }^{39}$ Thucydides describes as stasis the conflict that erupted between the different Hellenic city states, thereby leading to their 
destruction. Hobbes translated this negative sense of stasis not as civil war but rather as "sedition." The choice of words is significant. Even though sedition as a translation of stasis has an established Latin precedent, still sedition is something that cannot possibly be justified. Stasis as sedition is the destruction of the polis. This problem, which Aristotle would have described as the conflict between the different senses of equality, impresses upon Hobbes that what comes before the establishment of the political is not a paradise, but rather the inferno of sedition or stasis. In Augustine's paradise, God can speak directly to the protoplasts. In Hobbes' state of nature, the gods have departed to leave the stage to immanent destruction. And yet, the transcendent element is retained by Hobbes, but now transferred to the commonwealth, which needs a "mortal God" or sovereign to supervise over the cessation of sedition. In this sense, Hobbes' commonwealth is Augustine's Eden. The frontispiece of the Leviathan represents the sovereign as the Adam of the state, out of whose flesh the entire body politic is constructed. Except that the Adam/sovereign is given a transcendent dimension with characteristics of the divine. Both Hobbes and Augustine posit an ante-political equality in order to assert transcendent authority. The brute immanence of the state of nature or sedition can only be overcome by the introduction of a transcendent authority, which turns the "arrant wolfe" into a citizen subjected to authority.

The famous sentence from the Scholium to Proposition 35 from Part IV of the Ethics, according to which "Man is a God to man," is a riposte to Hobbes. This is not only because of the contrast between the structural similarity and conceptual discrepancy to the statement from De Cive. In addition, the development of the argument in Propositions 33-35 points squarely to an engagement with Hobbes. According to Proposition 33, "Men can disagree in nature insofar as they are torn by affects which are passions." The basis of disagreement is not, as in Hobbes, equality and freedom. Rather, it is the presence of passions. The Scholium to the following Proposition clarifies further: "it is far from true that they [i.e. humans] are troublesome to one another insofar as they love the same thing and agree in nature. Instead ... the cause of [their enmity] is nothing but the fact that (as we suppose) they disagree in nature." The fact that they have an equal right and license to love the same thing does not entail enmity, since enmity consists in being slave to passions that blind one from the fact that others have an equal right and freedom toward the same object. Instead, enmity arises from difference in nature, that is, in the differential power relations that can be both productive when pursued virtuously, and destructive when dominated by the passions. And Proposition 35 asserts: "Only insofar as men live according 
to the guidance of reason, must they always agree in nature." This guidance of reason is not separated from emotions. Indeed, it is bound up with virtue, which, according to Definition 8 of Part IV, is the same as potentia. Thus, reason includes the recognition of the differential power presented in the Axiom to Part IV, according to which everyone can be overpowered by an external cause. Potentia entails differential power. But the effect of this inequality of power is that "man is a god to man," which means that we need the other in order to create the space of contestation that makes democracy possible. This agonistic space does not require a transcendent authority to supervise over it and to regulate it, since it is the immanent unfolding of power relations. Thus, Spinoza's affirmation of power inequality is a riposte to Hobbes' supposition of an absolute ante-political equality, which legitimizes a sovereign power. This riposte is conducted in the name of democracy, by transforming the war of all against all to an agon of all against all. Differently put, the Axiom to Part IV precludes the possibility of a Hobbesian state of nature.

\section{Kant: Biopolitical power}

For Kant, the moral law produces freedom. But both the moral law and its freedom can never be fully accommodated within being. The fundamental premise of the moral law, as it is conceived by Kant, is that the particular is never the basis of moral judgment. We can see here the fundamental biopolitical move of positing a physical body, which may be capable of cognition, but which nevertheless needs to be supervised and normalized by a higher authority. This higher authority in Kant is the moral law, which, as is made clear in the Doctrine of Right, precedes politics. Kant establishes the moral law based on a notion of ante-political equality. In the Groundwork of the Metaphysics of Morals, Kant constructs this ante-political equality in the guise of the "Kingdom of Ends": "all rational beings stand under the law that each of them is to treat himself and all others never merely as means but always at the same time as ends in themselves. But from this there arises a systematic union of rational beings through common objective laws, that is, a kingdom, which can be called a kingdom of ends."40 Treating the other never as a means but only as an end in itself entails that the other is never measured. The other never becomes part of a calculation. This entails, first, that power relations between human beings are never a concern in such a kingdom of ends, which thus remains ante-political. Second, it entails an absolute equality between human beings, in the sense that from the perspective of the moral law, we are all absolutely equal. 
John Rawls clearly recognizes the Kantian strategy of asserting an antepolitical equality as the foundation for the justification of a biopolitical-and liberal-sense of sovereign power. ${ }^{41}$ The first part of the strategy is to assert that moral principles underwrite the political. As Rawls says, with explicit reference to Kant, "Once we think of moral principles as legislation for a kingdom of ends, it is clear that these principles must not only be acceptable to all but public as well." If the kingdom of ends and its categorical imperative point to a notion of humanity, if they are common to every human being, then this commonality itself becomes the basis for the "public," that is, for political authority. But this is not the same as politics itself, since "Kant supposes that this moral legislation is to be agreed to under conditions that characterize men as free and equal rational beings." The kingdom of ends can instate freedom and equality only because it is separate from the tumult of the everyday. It is in fact necessary, suggests Rawls, to think of it as prior to political authority, or, in his terms, as an "original position.” Rawls' indebtedness to Kant is explicit: “The description of the original position is an attempt to interpret this conception [i.e. the kingdom of ends]." ${ }^{42}$ The Kantian strategy consists in positing ante-political equality as separate from particularity, independent of immanent interests, and thus it is opposed to Hobbes' state of nature. Further, it is linked not to a non-human transcendent authority, but to an authority derived from humanity itself, which now becomes an end in itself.

We can find in the Ethics a response to this position too. The starting point is the equation of virtue and power according to Definition 8 of Part IV. This equation evades the Kantian position according to which there is a moral law to which every human action is answerable. If virtue is power, then instead of a law outside causality, human actions follow the patterns of the unfolding of power relations. This entails that the other is part of the system of calculation of power dynamics. Thus, in the Corollary 1 to Proposition 35 Spinoza avers: "There is no singular thing in Nature which is more useful to man than a man who lives according to the guidance of reason." In other words, "man is a god to man" so long as men realize the fundamental inequality of power relations. And Spinoza takes this thought to its logical conclusion in Corollary 2 to the same Proposition: "When each man most seeks his own advantage for himself, then men are most useful to one another." Human relations are power relations. This entails the opposite of Kant's position, namely, men are means to each other. There is nothing more ethical for Spinoza than this "kingdom of means." The recognition of the inherent usefulness of man to man is a principle of Spinoza's democracy. According to Proposition 37-which, significantly, according to the 
Scholium, concludes the discussion of "what the foundations of the state are"it is this inherent usefulness that leads to a sense of community: "The good, which everyone who seeks virtue wants for himself, he also desires for other men." The inequality of power relations does not have to lead to the exploitation of one man by another. Instead, the recognition of the inequality of power as the fact that differential power relations are the basis of interaction is the condition of participating and cooperating in the struggles and contestations that form society. More emphatically, there is society so long as there are these contestations. We cannot exist with others in a virtuous way unless we realize that, just like us, their aim is to increase their power. Differently put, human relationality is premised on power inequality whereby man is a means to others. We can be with others only if we are attuned to this power differential- that is, so long as we are attuned to static equality.

We have seen, then, that the thinking of equality within the Western philosophical and political tradition goes back to Aristotle's conception of geometric equality. The important aspect of geometric equality is that it guarantees a sense of authority. But the difficulty is that it cannot account for the competing claims of different articulations of geometric equality to hold sway over this authority. There is a civil war in nuce within geometric equality. To bypass this difficulty and to establish sovereign authority, an ante-political space of absolute equality is posited. Spinoza stands opposed to this triple move of equality. $\mathrm{He}$ challenges the establishment of authority through the Axiom to Part IV, which is incommensurable with the possibility of absolute power and which delineates a space in common. The Spinozan position allows for a conceptualization of equality which is not dependent on authority, but consists rather in the equality of access to participation in the differential unfolding of power.

\section{Notes}

1 For an account of the reception of Spinoza's thought, see Christopher Norris, "Spinoza and the Conflict of Interpretations," in ed. by Dimitris Vardoulakis, Spinoza Now (Minneapolis: University of Minnesota Press, 2011), 3-37. I am using the qualification "almost" to indicate the wide variety of interpretations of what Spinoza's conception of democracy consist in. For instance, whereas 
Leo Strauss is adamant that Spinoza "was the philosopher who founded liberal democracy," Negri on the contrary is equally adamant that Spinoza rejects liberal democracy in favor of what he calls "absolute democracy." See respectively Spinoza's Critique of Religion (New York: Schocken, 1965), 16; and, Antonio Negri, "Reliqua desiderantur: A Conjecture for a Definition of the Concept of Democracy in the final Spinoza," in Subversive Spinoza: (Un)contemporary Variations, trans. Timothy S. Murphy et al. (Manchester: Manchester University Press, 2004), 9-27.

2 This is not the case with the other important concept for democracy, namely, freedom. Spinoza thematizes freedom explicitly: for instance, the entire Tractatus Theologico-Politicus is, as the subtitle says, a defense of the "freedom to philosophize." And, there are numerous articles and monographs on Spinoza's conception of freedom - which are in fact so well-known that I will not list them here.

3 I know of only two articles which attempt to deal systematically with Spinoza's theory of equality: Michael Hoffheimer, "The Four Equals: Analyzing Spinoza's Idea of Equality," Philosophia, 15.3 (1985), 237-49, and, Beth Lord, "Spinoza, Equality, and Hierarchy," History of Philosophy Quarterly, 31.1 (2014), 59-78. They attempt to synthesize scattered remarks about equality in Spinoza's works. However none of them attempts to situate these remarks in relation the position that Spinoza rejects. I argue in this paper that it is crucial to understand Spinoza's engagement with the conception of equality, going back to Aristotle, which has dominated the Western philosophical tradition.

4 Aristotle, Athenian Constitution, in The Athenian Constitution; The Eudemian Ethics; On Virtues and Vices, trans. H. Rackham (Cambridge, MA: Harvard University Press, 1935), V.2.

5 Jacques Rancière discusses the Athenian election to office by lot with reference to Plato's Laws in Hatred of Democracy, trans. Steve Corcoran (London: Verso, 2006), 40-41. Opposing the Platonic critique, Rancière describes election by lot as the "scandal [which] lies in the disjoining of entitlements to govern from any analogy to those that order social relations" (41). Thus Rancière presents election by lot to accord with his own conception of democracy as based on the contingent and on the erasure of all hierarchies or "entitlements." But the Solonian innovation to elect officers of the state by lot is far less radical than Rancière wants it to be. In fact, according to The Athenian Constitution, election by lot is simply an expression of Solon's assertion of the virtue of every citizen, which is wholly in accord with the conception of geometric equality that Rancière is critical of.

6 See especially Jacques Rancière, Disagreement: Politics and Philosophy, trans. Julie Rose (Minneapolis: University of Minnesota Press, 1999); and, The Ignorant Schoolmaster Schoolmaster: Five Lessons in Intellectual Emancipation, trans. Kristin Ross (Stanford, CA: Stanford University Press, 1991). 
7 The important point is that, despite their similarities, Rancière retains a notion of the free will, while Spinoza does not. I develop this comparison in detail in my Democracy and Violence (forthcoming).

8 Antonio Negri, The Savage Anomaly: The Power of Spinoza's Metaphysics and Politics, trans. Michael Hardt (Minneapolis: University of Minnesota Press, 1991), 158. Filippo del Lucchese also says: "It would be difficult to exaggerate the importance of this axiom.... [T] his startling axiom ... can in any case serve as a backdrop to the entire Ethics." Conflict, Power, and Multitude in Machiavelli and Spinoza (London: Continuum, 2009), 52.

9 This also can be understood in a rather prosaic way: we are all subject to death to the extent that sooner or later there will be an external cause that is so much more powerful that it will end our life.

10 As a species of justice, equality is connected to the pursuit of virtue. Even though the link with virtue provides an initial point of contact with Spinoza, Aristotle qualifies equality in a specific, limited sense. See Aristotle, Nicomachean Ethics, trans. H. Rackham (Cambridge, MA: Harvard University Press, 2003), 1130b, 6-10.

11 Aristotle, Nicomachean Ethics, 1131b, 25.

12 Aristotle, Nicomachean Ethics, 1131b, 38.

13 The distinction between arithmetic and geometric equality can also be found in Plato. For instance, see Laws, trans. E.G. Burry (Cambridge, MA: Harvard University Press, 1961), 757, B-C. However, Aristotle's discussion in Nicomachean Ethics Book V is the most detailed one that has been preserved from ancient Greek philosophy.

14 I retain here the term "distributive justice" to describe geometrical equality because

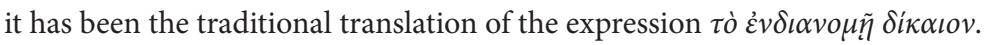
This is a misleading translation, given that distributive justice in English denotes the distribution of goods and wealth in a social or economic context. The word

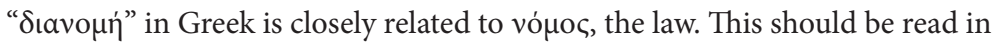
conjunction with Aristotle's assertion that "the actions that spring from virtue in general [i.e. the actions that are just] are in the main identical with the actions that are according to law" (Aristotle, Nicomachean Ethics, 1130b, 23-25). From this perspective, a more cumbersome but nevertheless more accurate rendering of

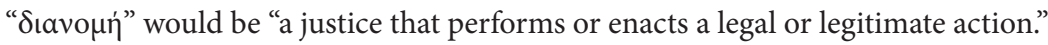
There is of course a lot more to say about the use of this word to denote justice from the perspective of geometrical equality, but I simply wanted to point out here the infelicitous translation of "distributive justice" into English.

15 Aristotle, Nicomachean Ethics, 1131b, 25-26. The strength of geometric equalitynamely, that it avoids the reductionism of measuring human relations by being based on a metier of equality-is also its greatest weakness, since such a metier is never self-evident. For a succinct presentation of this criticism, see Harry Frankfurt, “The Moral Irrelevance of Equality," Public Affairs Quarterly, 14.2 (2000), 87-103. 
16 Aristotle, Nicomachean Ethics, 1131b, 26-29.

17 I am saying "almost" so as to include the possibility that a sense of equality can exist which does not depend on geometric equality, such as Rancière's mentioned earlier.

18 John Rawls, A Theory of Justice (Cambridge, MA: Belknap Press, 1999, 2nd revised edition), see, for example, 104 and 122.

19 “Tautotita” [Identity], http://www.xryshaygh.com/index.php/kinima, my translation (accessed January 2014).

20 Lucchese, Conflict, Power, and Multitude, 52.

21 See my Sovereignty and Its Other: Toward the Dejustification of Violence (New York: Fordham University Press, 2013) and in Democracy and Violence (forthcoming).

22 Lucchese, Conflict, Power, and Multitude, 17.

23 Lucchese, Conflict, Power, and Multitude, 37.

24 Lucchese, Conflict, Power, and Multitude, 42.

25 I should note another terminological difficulty with the English translation of Aristotle at this point. At the opening of Book V, Aristotle introduces the issue of the metabole of constitutions. This does not mean revolution in the modern senses, whereby revolution denotes a break from the past-the establishment of a new authority and a new era. Instead, metabole means change or transformation from one state to another. This idea resonates with Aristotle's classification of the three possible constitutions, namely, democracy, oligarchy and aristocracy. Metabole denotes the transition from one of the constitutions to one of the other two. Book $\mathrm{V}$ is about revolution in the sense of metabole.

26 Aristotle, Politics, trans. H. Rackham (Cambridge, MA.: Harvard University Press, 1998), 1301a, 29-30, 31-32. Cf. Nicomachean Ethics, 1131b, 26-29.

27 Aristotle, Politics, 1302a, 23-24.

28 Aristotle, Politics, 1301a, 39-40.

29 Lucchese, Conflict, Power, and Multitude, 135.

30 Augustine, The City of God Against the Pagans, ed. and trans. by R.W. Dyson (New York: Cambridge University Press, 1998), XIV.10.

31 Augustine, City of God, XIV.26.

32 Augustine, City of God, XIII.21.

33 Augustine, City of God, XIV.13.

34 John Hick, Evil and the God of Love (New York: Palgrave Macmillan, 2010 [1st ed. 1966]), 212.

35 The opposite has been argued by various scholars. For instance, under the influence of Hobbes' own interpretation in his introduction to his translation of Thucydides, scholars have argued that the Greeks already had a conception of the state of nature understood as such an ante-political space. I think that this is a mistaken interpretation. I cannot take this issue up here, but I discuss it in detail in Chapter 2 of Sovereignty and Its Other. 
36 For the most detailed comparison between Spinoza and Augustine see Milad Doueihi, Augustine and Spinoza, trans. Jane Marie Todd (Cambridge, MA: Harvard University Press, 2010).

37 Thomas Hobbes, Leviathan, ed. by Richard Tuck (Cambridge: Cambridge University Press, 1999), 86-87.

38 Hobbes, De Cive, in ed. by H. Warrender, The Clarendon Edition of the Philosophical Works of Thomas Hobbes, vol. III (Oxford: Clarendon, 1983), \$1.

39 Hobbes' translation of Thucydides can be found in volume 8 of The English Works of Thomas Hobbes of Malmesbury, ed. by William Molesworth (London: John Bohn, 1839), volume 8.

40 Immanuel Kant, Groundwork of the Metaphysics of Morals, trans. Mary Gregor (Cambridge: Cambridge University Press, 2002), 41.

41 On the correlation between biopolitics and liberalism, see Michel Foucault's lectures The Birth of Biopolitics: Lectures at the Collège de France, 1978-79, ed. by Michel Senellart, trans. Graham Burchell (New York: Palgrave Macmillan, 2008).

42 Rawls, A Theory of Justice, 221.

\section{Bibliography}

Acampora, Christa Davis. Contenting Nietzsche. Chicago: University of Chicago Press, 2013.

Aristotle. Athenian Constitution, in trans. by Harris Rackham, The Athenian Constitution: The Eudemian Ethics: On Virtues and Vices. Cambridge: Harvard University Press, 1935.

Aristotle. Nicomachean Ethics, trans. by Harris Rackham. Cambridge: Harvard University Press, 2013.

Aristotle. Politics, trans. by Harris Rackham. Cambridge: Harvard University Press, 1998. Augustine. The City of God against the Pagans, trans. and ed. by R.W. Dyson. New York: Cambridge University Press, 1998.

Del Lucchese, Filippo. Conflict, Power, and Multitude in Machiavelli and Spinoza. London: Continuum, 2009.

Doueihi, Milad. Augustine and Spinoza. Translated by Jane Marie Todd. Cambridge, Mass.: Harvard University Press, 2010.

Foucault, Michel. The Birth of Biopolitics: Lectures at the College de France, 1978-79. Edited by Michel Senellart, translated by Graham Burchell. New York: Palgrave Macmillan, 2008.

Frankfurt, Harry. “The Moral Irrelevance of Equality”, Public Affairs Quarterly, 14.2 (2000), 87-103.

Golden Dawn. "Tautotita” [Identity]. Translated by the author. Accessed January, 2014. http://www.xryshaygh.com/kinima 
Hick, John. Evil and the God of Love. New York: Palgrave Macmillan, 2010.

Hobbes, Thomas. De Cive, in ed. by H. Warrender, The Clarendon Edition of the Philosophical Works of Thomas Hobbes, vol. III. Oxford: Clarendon, 1983.

Hobbes, Thomas. Leviathan, ed. by Richard Tuck. Cambridge: Cambridge University Press, 1999.

Hobbes, Thomas. The English Works of Thomas Hobbes of Malmesbury, vol. VIII, ed. by William Molesworth. London: John Bohn, 1839.

Hoffheimer, Michael. “The Four Equals: Analyzing Spinoza’s Idea of Equality”, Philosphia, 15.3 (1985), 237-49.

Kant, Immanuel. Groundwork for the Metaphysics of Morals, trans. by Mary Gregor. Cambridge: Cambridge University Press, 2002.

Lord, Beth. "Spinoza, Equality, and Hierarchy”, History of Philosophy Quarterly, 31.1 (2014), 59-78.

Negri, Antonio. The Savage Anomaly: The Power of Spinoza's Metaphysics and Politics. Translated by Michael Hardt. Minneapolis: University of Minnesota Press, 1991.

Negri, Antonio. "Reliqua desiderantur: A Conjecture for a Definition of the Concept of Democracy in the final Spinoza", in Subversive Spinoza: (Un)contemporary Variations. Translated by Timothy S. Murphy et al. Manchester: Manchester U. P., 2004, 9-27.

Nietzsche, Friedrich. On the Genealogy of Morality and Other Writings. trans. by Carol Diethe and ed. by Keith Ansell-Pearson. Cambridge: Cambridge University Press, 2006.

Norris, Christopher. "Spinoza and the Conflict of Interpretations," in ed. Dimitris Vardoulakis, Spinoza Now. Minneapolis: University of Minnesota Press, 2011, 3-37.

Plato. Laws. Translated by E.G. Burry. Cambridge, Mass.: Harvard University Press, 1961.

Rancière, Jacques. The Ignorant Schoolmaster Schoolmaster: Five Lessons in Intellectual Emancipation. Translated by Kristin Ross. Stanford: Stanford University Press, 1991. Rancière, Jacques. Disagreement: Politics and Philosophy. Translated by Julie Rose. Minneapolis: University of Minnesota Press, 1999.

Rancière, Jacques. Hatred of Democracy, trans. by Steve Corcoran. London: Verso, 2006. Rawls, John. A Theory of Justice, 2nd revised edition. Cambridge: Belknap Press, 1999. Strauss, Leo. Spinoza's Critique of Religion. New York: Schocken, 1965.

Vardoulakis, Dimitris. Sovereignty and its Other: Toward the Dejustification of Violence. New York: Fordham University Press, 2013.

Vardoulakis, Dimitris. Democracy and Violence (forthcoming). 